I cannot agree that a material that cannot take tensile stresses does not impose restrictions on the elastic constants. If the soil fails in tension it is no longer a continuum. Thus the stress in the $x$ direction should not produce tension in either the $y$ or $z$ direction. Under these conditions both values of Poisson's ratio will be restricted to being positive and my equation (1) will be restricted to the range $0-1$. The fact that the $A$ value may be outside this range is hardly proof of cross-anisotropy elasticity but more likely of non-elastic behaviour.

The reason for taking both values of Poisson's ratios as zero in those elements which were assumed to have failed in tension was because the use of any other value produced major changes in the stress distribution often effecting stresses in adjoining elements by values several times the magnitude of the applied surface load. With Poisson's ratios of zero the strains in the horizontal direction had no major effect on the stresses in the vertical direction of the same elements, and no appreciable overall effect. This is demonstrated for the Kars embankment where the deformations with and without allowing for tension were within $2 \%$ of each other and are represented by the same line on my Figs 10, 11 and 12.

\title{
REFERENCES
}

Christian, J. T. (1968). Undrained stress distribution by numerical methods. Jnl Soil Mech. Fdns Div. Am. Soc. Civ. Engrs 94, SM6, 1333-1345.

Dunlop, P. \& Duncan, J. M. (1970). Development of failure around excavated slopes. Jnl Soil Mech. Fdns Div. Am. Soc. Civ. Engrs 96, SM2, 471-493.

King, G. J. W. (1973). Discussion on prediction of undrained deformations and pore pressures in weak clay under two embankments. Géotechnique 23, No. 1, 133-135.

Skempton, A. W. (1954). The pore-pressure coefficients $A$ and $B$. Géotechnique 4, No. 1, $143-152$.

Skempton, A. W. (1960). Correspondence on the pore pressure coefficient in saturated soils. Géotechnique 10, No. 4, 186-187.

Terzaghi, K. (1943). Theoretical soil mechanics. John Wiley, New York.

\section{Accuracy of relative density measurements}

\author{
TAVENAS, F. and La ROCHELLE, P. (1972). Géotechnique 22, No. 4, 549-562.
}

\section{S. Serota and G. Lowther, Foundation Engineering Limited, London}

A growing amount of research based upon standard penetration test measurements is being carried out.

We have just completed some laboratory-controlled tests on methods of performing the standard penetration test. The results indicate that most operators are not giving the drivemonkey a truly free drop. This results in substantially higher measured standard penetration test values than for a free drop. It seems that the principal offenders are those using the sliprope and cat head.

The writers set up a test rig similar to that employed by Gibbs \& Holtz (1957) but the sand was tested dry only and at virtually one density.

The sand had the following properties. $\quad 113-117 \mathrm{lb} / \mathrm{ft}^{3}$ density, $117 \mathrm{lb} / \mathrm{ft}^{3}$ maximum density, $\Phi=45^{\circ}$ at $116 \mathrm{lb} / \mathrm{ft}^{3}$, specific gravity $=2 \cdot 64$, it was angular, well graded, $98 \% \frac{3}{16} \mathrm{in}$. and $1 \%$ passing the 200 sieve. Simulated overburden pressure was $2 \mathrm{lb} / \mathrm{in} .^{2}$

Several different methods of lifting and dropping a monkey of standard weight were tried, including the following. A slip rope and cat head on a Craelius diamond drill was used. The monkey had a hollow tail which was threaded over the top of the drill rods. The slip- 
rope was wound round the cat head either once, twice or three times. Another method used a Pilcon Automatic Free Fall Trip-Monkey which is screwed to the drill rods, the weight being lifted by a standard Wayfarer drill rig. A Dando Automatic monkey was also tested similarly. In a third method, the monkey as in the first method was lifted and dropped by hand without ropes and pulleys. The results are shown in Table 1.

Table 1 shows all results. Table 2 shows a direct comparison between the one-turn sliprope method and the Pilcon trip-monkey. In this table the two types of test were performed alternately in the same barrel of sand. Thus the average condition of the sand was identical in both types of test. The following conclusions can be drawn from these results.

The American Society of Testing and Materials method, which clearly specifies an absolutely free fall, is not satisfied if more than one turn of the rope is made on the cat head. It is noteworthy that in all the cat head tests the weight appeared to fall completely free. The standard penetration test for two or more turns corresponds very closely indeed with the results of Gibbs and Holtz (1957) (i.e. for a sand at $100 \%$ relative density under an overburden pressure of $2 \mathrm{lb} /$ in. $^{2}$ a standard penetration test of about 21 could be expected). Ireland et al. (1970) report that 'about two turns' are used in the Americas. Frydman (1970) reports a ratio of Pilcon trip-monkey standard penetration tests to two-turn cat head standard penetration tests of $1: 1.4$ in the same ground. It is interesting that the results in the table show the same ratio of approximately $1: 1.4$ for the slip-rope method between one turn and two or more turns on the cat head, and that when the weight of the driven assembly of the slip-rope and cat

Table 1

\begin{tabular}{|c|c|c|c|c|c|}
\hline Method & $\begin{array}{l}\text { Weight of } \\
\text { driven } \\
\text { assembly } \\
\text { including } \\
\text { rods and } \\
\text { spoon, } 1 \mathrm{~b}\end{array}$ & $\begin{array}{c}\text { Number } \\
\text { of } \\
\text { tests }\end{array}$ & $\begin{array}{l}\text { Average } \\
\text { standard } \\
\text { penetra- } \\
\text { tion test }\end{array}$ & $\begin{array}{l}\text { Standard } \\
\text { deviation }\end{array}$ & $\begin{array}{c}\text { Coefficient } \\
\text { of } \\
\text { variation, } \\
\text { per cent }\end{array}$ \\
\hline $\begin{array}{l}\text { Slip-rope and cat head } \\
\text { two or more turns } \\
\text { two or more turns } \\
\text { one turn } \\
\text { one turn }\end{array}$ & $\begin{array}{l}207 \\
275 \\
207 \\
275\end{array}$ & $\begin{array}{r}3 \\
3 \\
15 \\
27\end{array}$ & $\begin{array}{l}20 \cdot 67 \\
18 \cdot 7 \\
12 \cdot 7 \\
14 \cdot 3\end{array}$ & $\begin{array}{l}0 \cdot 9 \\
3 \cdot 3 \\
1 \cdot 6 \\
1 \cdot 4\end{array}$ & $\begin{array}{r}4 \cdot 6 \\
17 \cdot 6 \\
12 \cdot 3 \\
9 \cdot 6\end{array}$ \\
\hline $\begin{array}{l}\text { Pilcon trip monkey } \\
\text { Dando trip monkey }\end{array}$ & $\begin{array}{l}275 \\
249\end{array}$ & $\begin{array}{r}100 \\
12\end{array}$ & $\begin{array}{l}15 \cdot 5 \\
16 \cdot 2\end{array}$ & $\begin{array}{l}1 \cdot 9 \\
1.6\end{array}$ & $\begin{array}{l}12 \cdot 4 \\
10 \cdot 1\end{array}$ \\
\hline Hand & 207 & 18 & $16 \cdot 3$ & 1.9 & $11 \cdot 5$ \\
\hline
\end{tabular}

Table 2

\begin{tabular}{l|c|c|c|c|c}
\hline \multicolumn{1}{|c|}{ Method } & $\begin{array}{c}\text { Weight of } \\
\text { driven } \\
\text { assembly } \\
\text { including } \\
\text { rods and } \\
\text { spoon, } 1 \mathbf{b}\end{array}$ & $\begin{array}{c}\text { Number } \\
\text { of } \\
\text { tests }\end{array}$ & $\begin{array}{c}\text { Average } \\
\text { standard } \\
\text { penetra- } \\
\text { tion test }\end{array}$ & $\begin{array}{c}\text { Standard } \\
\text { deviation }\end{array}$ & $\begin{array}{c}\text { Coefficient } \\
\text { of } \\
\text { variation, } \\
\text { per cent }\end{array}$ \\
\hline $\begin{array}{l}\text { Slip-rope and cat head with one tur } \mathbf{n} \\
\text { Pilcon trip monkey }\end{array}$ & 275 & 12 & $15 \cdot 1$ & $1 \cdot 3$ & $8 \cdot 3$ \\
\hline
\end{tabular}


head apparatus was made identical to that of the Pilcon trip-monkey the standard penetration tests were almost identical. The inference is that the one-turn slip-rope method and the Pilcon trip-monkey, other things being equal, give the least impeded fall. The penalty for using two turns in the American Society of Testing and Materials method is to increase the standard penetration test by $40 \%$ due to impedance. This is evidenced by Frydman (1970) and possibly by Gibbs and Holtz (1957) if they followed what appears to be usual practice. The hand-drop, surprisingly, gives a higher standard penetration test than the one-turn sliprope with an equal driven weight, and our conclusion is that it is more difficult to release the weight instantaneously by hand than on the cat head. From the consistency of the results in the tables it is clear that the standard penetration test is quite reproducible. Free fall is much more difficult to achieve than most people imagine and, although a double turn on a cat head seems to clear freely, it does not do so. The trip-monkeys give the same standard penetration test as the one-turn slip-rope method. It is concluded that both comply with the American Society of Testing and Materials. The trip monkeys are thought to be the more reliable because the drop is really free and the height of drop is automatically regulated. Anyone correlating the results of standard penetration tests should first ensure that the tests comply with the American Society of Testing and Materials. A detailed account of our tests has been published (Serota and Lowther, 1973).

\section{REFERENCES}

Frydman, S. (1970). Discussion on the dynamic penetration test: a standard that is not standardized. Géotechnique 20, No. 4, 454-455.

Gibbs, H. J. \& Holtz, W. G. (1957). Research on determining the density of sands by spoon penetration testing. Proc. 4th Int. Conf. Soil Mech., London I, 35-39.

Ireland, H. O., Moretto, O. \& Vargas, M. (1970). The dynamic penetration test: a standard that is not standardized. Géotechnique 20, No. 2, 185-192.

Serota, S. \& Lowther, G. (1973). Ground Engineering 6, No. 1, 20-22.

\section{An investigation of a plane strain continuous penetration problem}

BUTTERFIELD, R. and ANDRAWES, K. Z. (1972). Géotechnique 22, No. 4, 597-617.

\section{A. Drescher, Polish Academy of Sciences, Institute of Fundamental Technological Research}

Tests identical to those reported by Butterfield and Andrawes were performed by Drescher et al. (1967) and were aimed at verifying applicability of different flow rules in predicting the velocity field during wedge penetration. A medium-dense sand and an analogue model composed of glass cylinders were used in the experiments. A theoretical analysis of both static and kinematic fields showed fair agreement with the assumption of incompressibility of flow and coaxiality between stress and strain rate tensors. Good agreement was obtained between the theoretical and experimental force-penetration curve although small oscillations of load were also detected.

The Authors' general statements about the advantages of the wedge penetration test are essentially the same as those contained in our paper (1967) but with one important exception. They make a statement about geometric similarity of flow during wedge penetration. This statement is erroneous because the effect of sand weight cannot be neglected. 